\title{
Recommendations to Mitigate Delay Causes in Kuwait Construction Projects
}

\author{
Ehab SOLIMAN* \\ Civil Engineering Department, Kuwait University, Kuwait, Kuwait \\ *Corresponding author: Ehab.solimanmoursi@ku.edu.kw
}

\begin{abstract}
Construction project delay is global problem in all construction industry. In Kuwait, there were many conducted research work aimed to identify delay causes in Kuwait construction projects. This paper aims to propose set of recommendations to mitigate effect of delays in construction projects in Kuwait. Rresults of previous research work were used as bases for propose recommendations. Previous research results are divided into five ranks (Top, highly, moderate, low, and very low ranked delay causes). Top causes are investigated and analyzed to identify why these top-ranked delay causes are happened and how to prevent their occurrence and/or mitigate their effect in case of occurrence. This research limited to provide proposals for top ranked only as it is more efficient. Most of these recommendations are oriented to governmental influencers. These recommendations contain revision and change project contract documents, shortening period for documentary session, changing contract conditions especially clauses of programming and delay analysis, and revise project awarding systems. These recommendations need governmental support to enhance project time performance in Kuwait. The results of this study can be used as a base for any effort to solve and dilute effect of delays in construction projects in Kuwait.
\end{abstract}

Keywords: project delay, recommendations, mitigation, Kuwait construction industry

Cite This Article: Ehab SOLIMAN, "Recommendations to Mitigate Delay Causes in Kuwait Construction Projects." American Journal of Civil Engineering and Architecture, vol. 5, no. 6 (2017): 253-262. doi: 10.12691/ajcea-5-6-5.

\section{Introduction}

Delaying project completion has many drawbacks for all project parties. Delay in project completion will postpone owner usage of project. For example, owner of oil production project may lose thousands of dollars for delaying oil production. For contractor, delaying project means that postponing equipment and staff releasing to use in new projects and increasing bank charges. Delays can lead to considerable negative effects such as lawsuits between owners and contractors. Sometimes, delaying project submission to governmental projects may make pressure for public and administration.

Kuwait is one of the Arabic gulf area. Kuwaiti GPD is about $\$ 174.810$ billion in 2014. The construction contribution to GPD is about $7 \%$. There are 177,696 persons working directly with this industry in Kuwait, [1]. Kuwaiti state is one of the gulf area, which characterized by highly economical changes and multi-cultural labor workforce. The majority of technical personnel are coming from many countries all-over the world. Many of international consulting and contracting firms are working in many of major Kuwaiti construction projects.

All public projects totally financed and ruled by governmental agencies such as ministry of public work (MPW), Ministry of Electricity and Water (MEW) and Kuwait Oil Company (KOC).
The usual project delivery system is the traditional method by assigning designer first then assign contractor. The usual awarding system in Kuwaiti governmental projects is least tender price contract via the Chamber of Central Tendering (CCT).

The used general contract document launched initially in 1971 and titled as "legal general contracts". This document is always one of contract document in governmental and private projects in Kuwait construction industry. In fact, many modifications applied to the original document, but the basic clauses remained as original. Last updating to this document was from more than 10 years (2003). Compared to which are used in the same region such as Qatar and Jordon. These countries changed their general contract document dramatically to be coincide with new FIDIC.

These days, many of mega projects are under construction in Kuwait. For example, Kuwait new university estimate cost 1.5 billion Kuwaiti dinar (Kuwait dinar is about 3.33 \$), planned to totally finish on 2022. New Kuwait airport estimated 1.4 billion Kuwaiti dinars, planned to finish on 2021, AlJahra new road way estimated 156 million Kuwaiti dinars anticipated to finish in 2018 and many other mega projects, which are a part of the general government development plan.

World Bank report [2] found that, during the implementation phase of infrastructure projects, cost overruns occurred in $20 \%$ of cases, while time overruns were estimated at more than $110 \%$. For example, Jaber 
Hospital, which is one of the largest central hospitals in Kuwait was delayed more than $90 \%$ from its original duration, and a delay fine of 18 millions KD were applied $(\mathrm{KD}=3.35 \$)$ and Governmental center for applying construction tests project is delayed more than $100 \%$ from its original duration. Minister of planning stated that $70 \%$ of governmental projects delay was due to executors rather than monitoring bodies, [3]. Many studies conducted in Kuwait to measure sources of delays in Kuwaiti construction industry. Most of these studies used questionnaire by asking construction personnel to identify and rank sources of delays. There is no clear recommendations were proposed to mitigate the effects of delays in construction projects in Kuwait. This study try to propose recommendations to mitigate occurrence and effect of delays in construction projects in Kuwait. These recommendations can be used to either prevent delay cause occurrence or mitigate its effect in case of occurrence. These recommendations may applied to enhance time performance in such construction industry environment.

\section{Objectives}

This work has two objectives:

- To Identify the most important delay causes in Kuwait construction industry

- To propose recommendations to mitigate effect and occurrence of delays in construction projects in Kuwait based on top-ranked delay causes analysis.

\section{Methodology}

Many published research work conducted to study delay causes in Kuwait construction projects. The first step is to collect all of the published research work regarding the study topic. More than twelve studies were collected, most of these research works aimed to identify and rank delay causes. Many problems is faced to use previous research work results directly such as difference of number of used delay causes, difference of participants groups and difference of phrases that describe delay cause. These problems should be handled to unify previous research work results. A generic absolute value is suggested to re-arrange results of previous research studies. The previous research work were divided into top, high, moderate, low and very low effect. The previous studies results were re-ranked based on the generic absolute value. This paper will concentrate only for resulted top-ranked delay causes because any effort to mitigate effects of top ranked delay causes will be more valuable and more efficient. Then, the list of top-ranked delay causes were grouped into five groups based on the area of influence. These delay causes groups will deeply analyzed. Searching for why these causes are occurred and how to mitigate their effect in case of occurrence. A set of recommendations are proposed for each group of top-ranked delay causes. At the end a list of recommendations was resulted based on each delay causes group analysis. These recommendations can affect one or more of top-ranked delay causes.

\section{Background}

\subsection{Construction Project Delay Globally}

A construction project delay is defined as the time during which part of the construction project has been extended beyond what was originally planned due to unanticipated circumstances [4] or the time overrun beyond project delivery date [5]. Kaming et al [6] defined delay as the extension of time beyond planned completion dates traceable to the contractors.

In UK, a report published stated that $70 \%$ of the construction projects carried out by public departments and agencies completed late. Moreover, a research by the Building Cost Information Service (BCIS, UK) found that nearly $40 \%$ of all studied construction projects had overrun the contract period [7].

Al-Ghafly [8] found that the percentage of delayed projects in Saudi Arabia varied from 35\% to 84\%. This project delay was not recorded in the traditional projects, it is also recorded in green buildings projects. Percentage of $32.29 \%$ of the green construction projects completed behind schedule [9].

As described above, the problem of delays in construction projects is significant and global problem. Therefore, searching for causes of delays and attempts to mitigate their effects is a valid and worthwhile effort.

Many of previous, globally research work conducted to identify and rank delay causes in construction projects.

For example, Alaghbari et [10] studied the significant factors causing delay of building construction projects in Malaysia, Assaf and Al-Hajii [11] searched for causes of delay in large construction projects in Saudi Arabia, Ahmed et al [5] studies the delay causes in Florida, USA and Shebob et al [12] analyzed construction delay factors in building construction project in Libya. There are many other studies were conducted all-over the world to identify sources of delay in construction projects.

\subsection{Delay Causes in Kuwait Construction Industry}

In Kuwait, many research works conducted to identify and rank delay causes in construction projects. Many published research work conduct in this area, also there are many of non-published studies as part of many courses in civil engineering department - Kuwait University. Some of research work were generic and aimed to identify delay causes without ranking. For example, Sami and Kartam [13] identified delay causes based on limited number of completed projects. Kushki and Kartam [14] studied the effect of construction material shortage on time overrun in Kuwait construction projects. Soliman [15] identified the miscommunication problems that lead to project delay. Eight of the previous studies aimed to identify and rank delay causes. The results of these studies identified ranking of surveyed delay causes based on different procedures for ranking. Table 1 shows research procedures for these eight published studies.

First, Karatm and Kartam [16] studied risk elements that affecting delaying construction projects in Kuwait 
industry. They used 26 predefined risk factors of project delay in Kuwait construction industry. They use weighted scores to rank delay risk elements. They concluded that the top ranked were: material unavailability and financial problems.

Al-Tabatabi [17] made a survey to rank delay causes in governmental construction projects. He used a questionnaire of 53 delay causes. He used RII relative importance index to rank these delay causes. The top ranked delay causes as stated by Al-Tabtabi [17] were: slow financial and payment procedure, Slow-decision making process, lack of planning and use of CPM, poor scheduling of subcontractors and lack of design drawings coordination

A different study by Kushki et al [18] was conducted to search for delay of causes of private residential buildings. They used the delay in months to rank a set of pre-fined delay factors.

Al Zubadi and Al Otaibi [19] searched for risk factors for time overrun in building and infrastructure projects. The five most critical time-overrun factors identified in Kuwait's infrastructure and building projects are: delay in government approvals/permits, delay in preparation and approval in variation orders, client induced additional work beyond the original scope, changed engineering conditions from the contract document and decreased labor productivity due to extreme climatic conditions.

Soliman [20] surveyed delay causes in Kuwaiti construction industry. He used a questionnaire of 30 delay causes and he used performance index to rank delay causes. The most important delay causes as per Soliman [20] study were: owner financial problems, conflict between contractor and consultant, contractor financial problems and delaying of contractor payments from owner.

AlMarri et al [21] discussed sources of delays in highway projects in Kuwait as an example of infrastructure projects.
They used thirty delay causes divided in five groups based on project time stages. They found that the most important reasons of delay in highway construction projects were not only during the construction stage of the project but also during all stages of the project. They concluded that the most important delay causes in such type of projects were: coordination between the ministries in the implementation of projects, multiplicity of agencies should be to obtain approvals, the rising cost of project and delay receipt of the contractor project documents by the owner advisory.

Almutairi [22] discussed sources of delays in general Kuwait construction industry. He continued the same procedures of searching for delay causes by questionnaire distributed for selected construction personnel. The most important delay causes as per this study were: using lowest price bidding system, poor performance of main contractor, inadequate performance of main contractor and delay of payments from client. AlSanad [23] discussed risk factors that affect delay in Megaprojects in Kuwait. A total of 54 perceived risk factors which categories into six groups have been identified and prioritized on the basis of criticality in the construction mega project. The ten most significant risks according to interview participants were: the length of the documentary cycle during the project lifecycle, variation order to project during the construction phase, delay in paying subcontractors invoices, technical difficulties in obtaining utility permits and lack of financial resources and cash flow problem of partners.

Previous studies used different phrasing for identifying sources of delays, Karatm and Kartam [16] and AlSanad [23] used risk factors, while all others used delay causes or delay factors. The studies can give a general view for Kuwait construction industry and identifying the most important problems that resulting from project delays in Kuwait construction industry.

Table 1. Previous research work regarding measuring and ranking of Kuwait project delay

\begin{tabular}{|c|c|c|c|c|c|c|c|c|}
\hline Res. No & 1 & 2 & 3 & 4 & 5 & 6 & 7 & 8 \\
\hline Authors & $\begin{array}{l}\text { Kartam \& } \\
\text { Kartam }\end{array}$ & AlTabtabi & $\begin{array}{c}\text { Koushki } \\
\text { etal }\end{array}$ & $\begin{array}{c}\text { Al Zubadi and Al } \\
\text { Otaibi }\end{array}$ & Soliman & $\begin{array}{l}\text { Al-Marri } \\
\text { et al }\end{array}$ & Almutairi & AlSanad \\
\hline Year of Publ. & 2001 & 2002 & 2005 & 2008 & 2010 & 2012 & 2016 & 2017 \\
\hline Project Owner & N/A & Public & private & public & N/A & public & N/A & N/A \\
\hline Project Type & N/A & $\begin{array}{l}\text { housing and } \\
\text { building }\end{array}$ & residential & $\begin{array}{l}\text { Building and } \\
\text { Infrastructure }\end{array}$ & N/A & N/A & N/A & N/A \\
\hline $\begin{array}{l}\text { Method of Data } \\
\text { Gathering }\end{array}$ & $\begin{array}{c}\text { Mailed } \\
\text { questionnaire }\end{array}$ & $\begin{array}{c}\text { Mailed } \\
\text { questionnaire }\end{array}$ & \begin{tabular}{c|} 
Mailed \\
questionnai \\
re
\end{tabular} & Mailed questionnaire & $\begin{array}{c}\text { Interview } \\
\text { Questionnaire }\end{array}$ & $\begin{array}{l}\text { questionna } \\
\text { ire }\end{array}$ & questionnaire & questionnaire \\
\hline $\begin{array}{c}\text { No of } \\
\text { Participants }\end{array}$ & $\begin{array}{l}\text { Contractors } \\
\text { (35) }\end{array}$ & $\begin{array}{c}\text { Owners (23), } \\
\text { Consultants (8) } \\
\text { \& Contractors } \\
\text { (17) }\end{array}$ & $\begin{array}{l}\text { owners } \\
\text { (450) }\end{array}$ & $\begin{array}{c}\text { Governmental } \\
\text { Engineers (25), } \\
\text { Contractors (28 and } \\
\text { Consultants (27) }\end{array}$ & $\begin{array}{c}\text { Owners (5), } \\
\text { Consultants } \\
\text { (16) \& } \\
\text { Contractors (9) }\end{array}$ & $\begin{array}{l}\text { constructi } \\
\text { on } \\
\text { personnel } \\
(60)\end{array}$ & $\begin{array}{l}22 \text { from } \\
\text { clients, } \\
\text { contractors } \\
\text { and } \\
\text { consultants }\end{array}$ & $\begin{array}{c}\text { Owners (61), } \\
\text { Consultants (107), } \\
\text { Contractors (61) \& } \\
\text { Others (108) }\end{array}$ \\
\hline $\begin{array}{c}\text { No of Used } \\
\text { Delay Causes }\end{array}$ & 26 & 53 & 8 & 33 & 30 & 3 & 40 & 56 \\
\hline $\begin{array}{c}\text { No of Delay } \\
\text { Causes Groups }\end{array}$ & 1 & 8 & 1 & 1 & 6 & 1 & 1 & 6 \\
\hline $\begin{array}{c}\text { What Asked for } \\
\text { Participants }\end{array}$ & $\begin{array}{c}\text { Significant in } \\
\text { three levels } \\
\text { and } 10 \text { points } \\
\text { rank } \\
\end{array}$ & $\begin{array}{c}\text { Importance in } 5 \\
\text { levels }\end{array}$ & $\begin{array}{l}\text { effect on } \\
\text { project } \\
\text { delay in } \\
\text { (months) }\end{array}$ & $\begin{array}{c}\text { Significance and } \\
\text { Frequency in } 5 \text { levels }\end{array}$ & $\begin{array}{c}\text { Importance in } 5 \\
\text { levels }\end{array}$ & $\begin{array}{l}\text { Importanc } \\
\text { e in } 5 \\
\text { levels }\end{array}$ & $\begin{array}{l}\text { Importance in } \\
5 \text { levels }\end{array}$ & $\begin{array}{c}\text { Importance in } 5 \\
\text { levels }\end{array}$ \\
\hline $\begin{array}{c}\text { Technique Used } \\
\text { to Delay Cause } \\
\text { Rank }\end{array}$ & weight score & $\begin{array}{l}\text { RII relative } \\
\text { importance } \\
\text { index }\end{array}$ & months & Criticality Index (CI) & $\begin{array}{l}\text { Importance } \\
\text { Index }\end{array}$ & $\begin{array}{c}\text { mean } \\
\text { values for } \\
\text { importanc } \\
\text { e level }\end{array}$ & $\begin{array}{l}\text { RII relative } \\
\text { importance } \\
\text { index }\end{array}$ & $\begin{array}{c}\text { RII relative } \\
\text { importance index }\end{array}$ \\
\hline $\begin{array}{l}\text { Technique Used } \\
\text { to Get Rank } \\
\text { Agreement for } \\
\text { Groups }\end{array}$ & NO & $\begin{array}{l}\text { Rank } \\
\text { Agreement } \\
\text { Factor }\end{array}$ & $\mathrm{NO}$ & NO & $\begin{array}{l}\text { Rank } \\
\text { Agreement } \\
\text { Factor }\end{array}$ & NO & $\begin{array}{l}\text { Rank } \\
\text { Agreement } \\
\text { Factor }\end{array}$ & NO \\
\hline
\end{tabular}


Although too many studies have been conducted allover the world, these studies have limited effect in solving the difficulties with these delay causes [24].

In this study the results of these eight studies will be used for propose delay causes recommendation to mitigate effect of delays in Kuwait construction projects.

\subsection{Delay Mitigation Procedures}

The usual procedures to mitigate effects of delay in case of occurrence is adding more resources to definite activities, fast tracking or project crashing especially in contractor responsible delays. It is important to predict and identify the problems in the early stages of construction and diagnose causes of delays to find and implement the most appropriate procedures to delay effect mitigation [25].

Some of researches conducted to propose recommendations to mitigate delays in many places Abdul-Rahman et al [26] suggested procedures for delay mitigation in Malaysian construction industry. Their proposal based on interview with technical personnel. The suggested procedures were increasing productivity by working overtime hours, shifts, etc., execute the delayed activities by subcontractors and increase site meetings with all functional groups. Hamza et al [27] proposed another proposal to delay mitigation by enhancing knowledge management by using a project learning approach. They proposed a model that integrates knowledge management, project learning and lessons learnt. The results indicate that the best way to meet the requirements of the owner and the market is by applying the project learning in line with the project program and this can be done by maintaining the contractor's core proficiency. The lessons learnt during the projects need to be recorded and how those difficulties were attempted would be of huge help and guidance to the future projects of similar nature.

Rani and hinge [28] proposed a theoretical mitigation plan for 48 delay causes recorded from previous researches. This proposed plan is generic and difficult to practical apply.

Dolage and Pathmarajah [29] suggested ten recommendations to mitigate delay causes effect in large construction projects in Sri Lanka. These recommendations were only for contractor from consultants' point of view.

Srdić and Šelih [30] recommended that more attention should be paid to the processes that are taking place prior to construction, such as producing adequate design drawings and documents to mitigate effect of delays.

Most of this research work tends to propose recommendations based on different construction environment and different project types. Most of these recommendations are very generic and not to practically applied in many construction industry environment. This study will propose recommendations based on real studies regarding delay causes for Kuwait construction industry.

\section{Discussion}

\subsection{Top Ranked Delay Causes in Kuwait Construction Projects}

As shown in Table 1, all previous published studies used questionnaire by asking participants from construction industry to assess frequency and level of impact of predefined some of delay causes. There are many problems to use results of these studies directly. First, the surveyed studies used many of similar delay causes in different phrases. For example Soliman [20] used phrase "shortage of construction material" to represent difficulty of providing construction materials, while Al-Tabtabai [17] used phrase "unavailability of construction materials in the local market" to represent the same problem. To solve this problem, all different phrases that have the same meanings will dealt as one delay cause.

There is another problem; the studies used different group of delay causes, different method of analysis and different participants' categories and theses participants' categories are different in opinions and objectives as shown in Table 1.

To deal with this problem, an absolute ranking considered for previous studies in spite of changing in participants' groups ranking. For example in Soliman study [20], contractor financial problems ranked second from consultants' judgment, while contractors ranked this delay cause as sixth. An absolute value calculated by adding the two values of ranks to represent an absolute value for both groups. A revised rank will be resulted by using the resulted absolute values as shown in Table 2.

To deal with different surveyed number of delay causes, it is noticed that all of the previous research work used five rating scales to identify frequency and level of impact of delay causes. To deal with this problem, the study result ranking for the delay causes assumed as five rank categories:

- $\quad$ Top ranked delay cause, (T)

- $\quad$ High ranked delay cause (H)

- Average ranked delay cause (A)

- Low ranked and (L)

- Not important or not effective delay cause (N)

The resulted delay cause ranked is divided into these five ranks. If the delay cause was in the top $20 \%$ of the delay cause ranking, it can be assumed as top ranked. If the delay cause rank was on the smallest $20 \%$ of the delay causes ranked, it can be assumed, as these delay causes have no effect on project delays. Based on the above assumptions, Table 2 shows revised ranking for Soliman study-2010. The same procedure is applied for others.

By gathering the top $20 \%$ of delay causes from each study, twenty-five causes were top ranked from previous studies. Table 3 shows the top ranked causes of delays which are resulted from previous studies. These top ranked delay causes can be divided into these groups based on who or which is the influencer:

1. Contractual and governmental procedures related problems

2. Local Construction industry related problems

3. Special Site / project management related problems

4. Financial related problems

5. Planning and control procedure and skills related problems

This study will be limited to analyze these top ranked delay causes and recommend delay cause mitigation procedures for top ranked delay causes recorded in Kuwait construction industry. It is more efficient to suggest recommendations for top ranked delay causes instead of propose generic recommendations. Each group of top ranked delay causes will be analyzed to propose set of recommendations for delay causes mitigation. 
Table 2. Absolute Value And Re-Ranking For Soliman 2010 Study

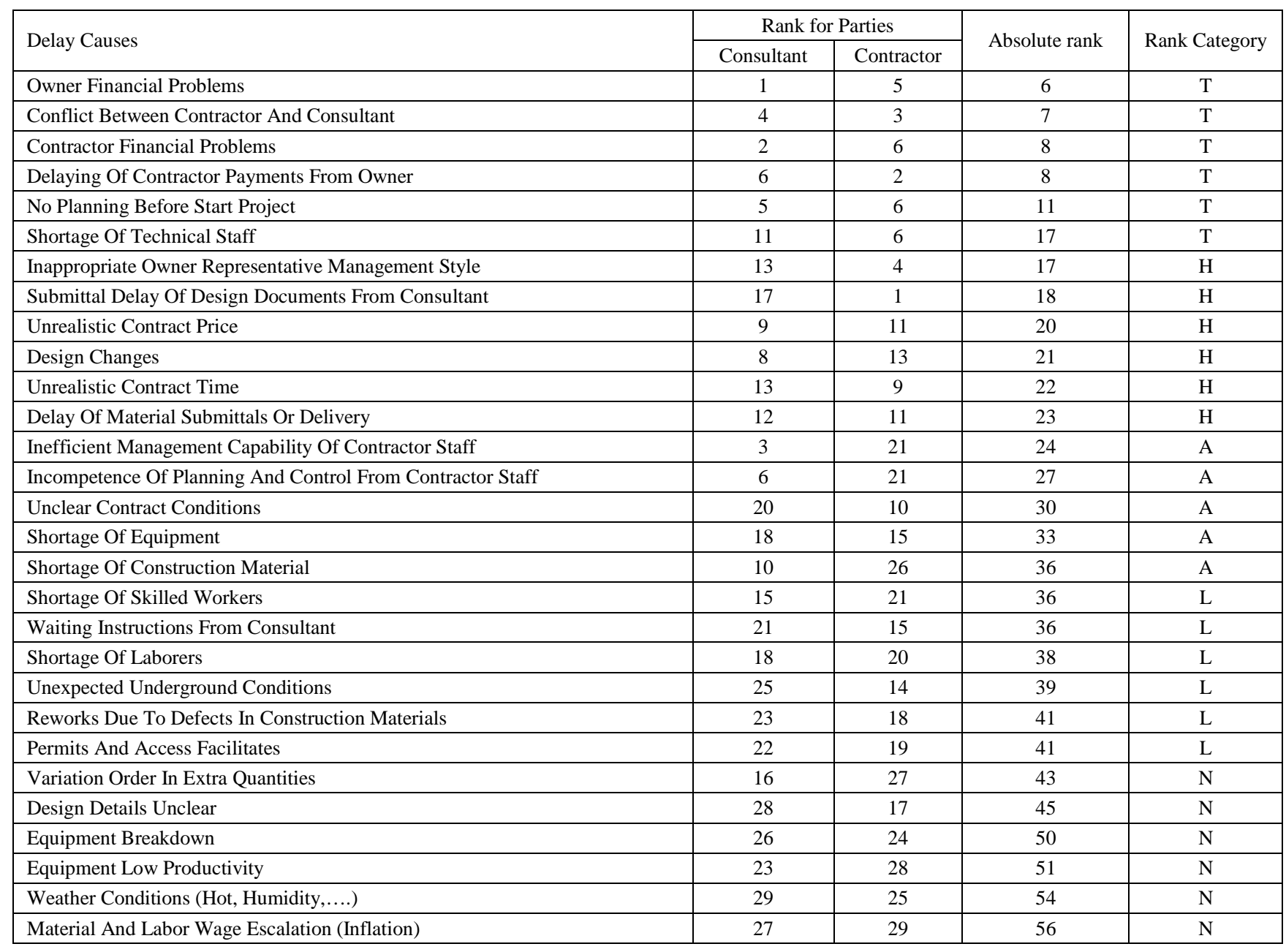

Table 3. Top-Ranked Delay Causes and Groups

\begin{tabular}{|c|c|c|}
\hline No. & delay cause & Delay Cause Groups \\
\hline 1 & Delay in preparation and approval in variation orders & Contractual and governmental \\
\hline 2 & Changed engineering conditions from the contract document & Contractual and governmental \\
\hline 3 & Slow-decision making process & Contractual and governmental \\
\hline 4 & Delay in government approvals/permits related to project & Contractual and governmental \\
\hline 5 & Risk allocation mainly on the contractor & Contractual and governmental \\
\hline 6 & Decreased labor productivity & Local Construction industry \\
\hline 8 & Shortage of technical staff & Local Construction industry \\
\hline 9 & fluctuating productivity levels & Local Construction industry \\
\hline 10 & defective design & Project Management skills \\
\hline 11 & lack of design drawings coordination & Project Management skills \\
\hline 12 & coordination with sub-contractors & Project Management skills \\
\hline 13 & limited authority among supervision staff & Project Management skills \\
\hline 15 & Client induced additional work beyond the original scope & Project Management skills \\
\hline 16 & Conflict between contractor and consultant & Project Management skills \\
\hline 17 & Contractor financial problems & financial \\
\hline 18 & financial failure & financial \\
\hline 19 & Owner financial problems & financial \\
\hline 20 & slow financial and payment procedure & financial \\
\hline 21 & Delaying of Contractor payments from owner & financial \\
\hline 22 & Unrealistic design development periods & plan-programming skills \\
\hline 23 & lack of planning \& control on the side of the subcontractors & plan-programming skills \\
\hline 24 & lack of planning and use of CPM & plan-programming skills \\
\hline 25 & poor scheduling of subcontractors & plan-programming skills \\
\hline
\end{tabular}




\subsection{Recommendations for Delay Causes Mitigation}

In this section, each group of delay causes will be discussed, analyzed then propose a set of recommendation to mitigate effect of each group of delay causes.

\subsubsection{Contractual and Governmental Procedures Related Problems}

This group contains delay causes that affected by governmental procedures, laws and contracts used in Kuwait construction projects. Five top ranked delay causes were recorded as shown in Table 3, which are:

- Delay in preparation and approval in variation orders

- Changed engineering conditions from the contract document

- Slow-decision making process

- Delay in government approvals/permits related to project

- Risk allocation mainly on the contractor

These delay causes are resulted from three main features in Kuwait; the used procedure for variation order, governmental approval procedures and the used general contract document.

Kushkai et al [14] revealed that a number of variation orders issued during the construction phase led to both delays and cost increases in residential projects in Kuwait. The projects that experienced variation orders incurred more than 58\% time delay and cost increases when compared to those with no variation orders. Alaryan et al [31] studied the causes of changing orders in Kuwait private and public projects, they revealed that the first cause to changes orders are which related to owner management procedures.

In Kuwait especially in governmental projects, issuing changing order approval is one of top management responsibility. Officially, changing order is starting from site people then they propose changing order to top management. The changing order should be attached with time and cost impact. If change order increases certain amount, it needs approval from governmental auditing agencies. The changing order cannot officially started without taking official approval from top management. Therefore, it takes too long time to approve and issue a change order [32].

Globally, there are many recommendations were proposed to control consequence and drawbacks of changing order in construction industry. Charoenngam et al [33] suggested a web-based change order management system that supports documentation, communication and integration between different team members in the change order workflow to manage change order procedure. Halwatura and Ranasinghe [34] proposed that increasing communication channels and hire professional planning staff would reduce occurrence of changing orders in projects. Msallam et al [35] proposed an administration system that could reduce variation orders in Jordanian highway projects. The system applications covers all project stages (conceptual, design and construction) and collect all project rulers (owner, consultant and contractor). The proposed system concentrate more on studying and analyzing documents in all stages and provide more time for design and provide increased revision periods in order to control issuing change orders.

In general, it is recommended to revise all changing order functions and purpose of change orders in Kuwait construction industry. Increasing communication channels between all project parties during all project stages and defining time frame for each step of changing order procedures in governmental projects will mitigate drawbacks of change orders in Kuwaiti construction projects.

There is another problem regarding delaying governmental agencies approvals. In fact, there are many governmental agencies have contribution to launch a new governmental project. These agencies always take too long time to approve initiation a new project. General bureau of auditing, ministry of financial, sector of legislation and opinion, ministry of public works, ministry of water and electricity and municipality are samples of agencies that should approve launching a new governmental project. Recently, a new procedure assigned to unite agencies for launching a new governmental project. Kuwaiti government assigned the supreme council for planning and development (SCPD) to launch and control projects, which are listed in its general plan. SCPD report [36] recommended accelerating process of agencies approval by changing and fast-tracking documentation cycle for getting approval and revision for new projects.

Regarding general contract document, that defines relationship and risk allocation for project parties. This document called "legal general contracts" which is a vital obstacle in Kuwait construction industry. This document initially issued in 1971. This document is one of any contract document in governmental and private projects in Kuwait construction industry. In fact, many modifications applied to the original document, but the basic clauses remained as original. Last updating to this document was from more than 10 years (2003). Because of old fashioned of this document, many clauses added to project particular conditions to overcome illness of the used general conditions document.

There is another problem related to the used general contact. It defines steps to be followed in case of delay (clause no 44), but there is no definite clause to define the procedure for dispute resolution. A dispute is arisen in site because of many reasons and to resolve this dispute a clear and definite approach should followed by all parties. FIDIC [37] defines a dispute committee (DAB) to quick resolve project dispute between project parties. It is recommended to revise the used general condition document in Kuwait to be more up-to-date. Comparing to which is used in the same region such as Qatar and Jordon, they changed their general contract document dramatically to be coincide with new FIDIC.

\subsubsection{Local Construction Industry Related Problems}

This group contains delay causes related to construction industry infrastructure, which contains availability of construction materials, labor force and equipment. From the recorded top ranked delay causes, these delay causes were recorded:

- Decreased labor productivity

- Labor, materials and equipment availability

- Shortage of technical staff

- Fluctuating productivity levels 
Most of these causes resulted from labor force who working in construction industry in Kuwait. Most of them are coming from abroad especially from east of Asia [38]. The common procedure for labor supply is via a governmental visa. Governmental visa regulations exposed to changes frequently. To solve this problem, there are two recommendations. It is recommended to change labor supply procedure from abroad especially for big or mega projects. It is also recommended to establish educational and training centers to qualify labor force to enter Kuwaiti construction industry. This training centers can provide its service to prepare local Kuwaiti people to be a construction laborer. Unfortunately, there is no construction institute give regular or formal education and training to qualify labor force in Kuwait. In spite of there is an institute for construction training belongs to PAAET (public authority for applied education and training), but it graduates assistant engineers who are responsible for monitor labor force not working as construction laborers.

Another problem regarding labors in Kuwait is the fluctuating productivity rates. Productivity rate are fluctuated because many multi-nationalities who are working in industry and they are coming from different environments, backgrounds, languages, education and training. Many problems resulted from labor multinationalities. Many of research work studied the effect of multi-cultural and language changes in communication problems in construction projects [39]. Loosemore and Lee [40] discussed the communication problems in Australian and Singaporean construction industry due to changes of spoken and written languages between managers and operatives of multi-cultural community.

\subsubsection{Project Management Skills Related Problems}

This group contains the delay causes that affected by project awarding either to contractor or consultant, and inefficiency of project leaders such as owner, contractor or consultant or subcontractors. The top ranked delay causes related to this group were:

- Inadequate contractor experience

- Limited authority among supervision staff

- Coordination with sub-contractors

- Defective design

- Lack of design drawings coordination

- Client induced additional work beyond the original scope

- Conflict between contractor and consultant

This group of causes is resulted from three major features that related to Kuwait construction industry which are procedure for project awarding system, lack of procedure for dispute resolution and designer awarding procedure.

In Kuwait construction industry, it is usual to award project by traditional approach to the lowest bidder especially in governmental projects. Inexperienced contractors, problems with subcontractors, contractor financial problems, conflicts between project parties are examples of drawbacks resulted from low bid price procedure. The low bid process creates many numbers of problems such as not being on time and within budget [41]. These problems of lower bidder approach are occurring in Kuwait construction industry and may be worse. Many researches proposed different techniques to contractor selection and awarding. Most of these proposed approaches tried to match owner objectives with contractor objectives. Kashiwagi [42] proposed a system called performance information procurement system (PIPS) instead of lower bidder by filtering selected bidder in four steps. Alzara et al [43] proposed to use PIPS to mitigate anticipated delays for campus of university in Northern of Kingdom of Saudi Arabia. It is recommended to review and revise projectawarding system used in Kuwait especially in large governmental projects. Changing awarding system may mitigate problems of using lowest price strategy.

In addition to, appointing designers in Kuwait construction industry especially in governmental is depending on consultants' evaluation, which is based on technical and cost criteria. In past, project delivery for designer was based on an invitation from ministry to selected number of consultant firms. This invitation was based on past performance and reputation of consultant. Recently, the procedure for consultant qualification is changed. The consultant qualification now is under a governmental committee belongs to supreme council for planning and development (SCPD), which now responsible for consults prequalification and appointment for all governmental projects. Consultant project qualification takes into consideration many criteria such as consultant experience, recorded performance, experience with such type of projects, and government agencies evaluation for consultant firm. Although, these criteria are very important to evaluate consulting firm, but it is recommended to add many of criteria such as consultant firm financial capability, availability of technical staff, matching technical staff with project requirements..

\subsubsection{Financial Related Delay Causes}

This group contains all delay causes that are resulted from financial problems. This group contains the following delay causes as presented in Table 3:

- Contractor financial problems

- Financial failure

- Owner financial problems

- Slow financial and payment procedure

- Delaying of Contractor payments from owner

These causes are resulted from either local or governmental reasons such as decreasing oil prices, which is the main source of country economic. The global reasons can affect owner and contractor financial capabilities. Oil prices decreasing may affect financial capability of owner, especially public owners. In other hand, some of private owner reschedule their projects after the financial crises in 2008.

Contractor financial problems might resulted from either bad financial management in site project level or in the contractor company level. This bad financial management caused by unrealistic project price or cost estimate deficiency from contractor side. Using low price strategy for project delivery system may force contractor to reduce his profit percentage in order to project awarding and after that, the contractor will find himself in financial problems and un-capability to finance project. It is recommended to change project-awarding system from lowest price strategy to another strategy as mentioned 
before. It is recommended to revise the procedure to project awarding to make sure that the contractor has the adequate financial ability to finance project. Many of research work have proposed to evaluate contractor financial capability as one of prequalification criteria. This procedure may force contractor to submit financial statements, bank arrangement facilities and others in his prequalification papers.

Problem of delaying contractor payments from owner side is common in Kuwait construction projects. This delay will affect contractor ability to finance resulting in negative project cash flow. There is no penalty clause for delaying contractor payment. In FIDIC 1999, the contractor may claim owner for delaying contractor payment (clause no.14.8). It is recommended to change general condition document by adding a penalty clause for delaying payments.

\subsubsection{Project Planning and Control Skills Related Problems}

This group contains all delay causes that affected by inefficiency of project planning and controlling procedure. This group contains the following delay causes as shown in Table 3

- Unrealistic design development periods

- Lack of planning and use of CPM

- Lack of planning \& control on the side of the subcontractors

- Poor scheduling of subcontractors

Planning and schedule importance in project management is undoubted. Many researches identified influence of efficient planning and control process in project success [44].
In Kuwait efficiency of planning, scheduling and control process in construction industry is low as shown in Table 3. This deficiency is resulted from weakness of planning clauses in the used general conditions and deficiency of planning skills for who are working in construction industry in Kuwait.

Kuwaiti governmental general contract (2003) clause 14 stats that:... it is essential for contractor to submit project program prior to project start. In clause 46, which is regarding work progress stated that: ...the contractor has to accelerate his work progress if the work is delayed. These clauses lack of defining time frame to submit project original program. There is no obligatory clause to encourage contractor to revise periodically original baseline program and lack of penalty for fail of submitting revised program. While, FIDIC [37] defines time frame to submit project program within 28 days from project start and forces contractor to submit program progress updating, revised schedule whenever required (clause 8.3).

It is recommended to change clauses of planning and control in the used general contract in Kuwait to be coincide to FIDIC by defining time frame to submit original program and to force contractors to submit project program revised or updating..

It is very important to enhance planning and control skills for all project parties. It is recommended to define prerequisite skills for project planner such as experience, working in similar projects, having adequate educational and technical skills to monitor project. It is highly recommend to enhance planning and controlling skills especially for owner side. This enhancement can be executed by training courses or providing site training for all project management rulers.

Table 4. Recommendations for delay mitigation and effect on top ranked delay causes

\begin{tabular}{|c|c|c|c|c|c|c|c|c|c|}
\hline \multirow{2}{*}{ Delay Cause } & \multicolumn{9}{|c|}{ Recommendation Number } \\
\hline & R1 & $\mathrm{R} 2$ & R3 & R4 & R5 & R6 & R7 & R8 & R9 \\
\hline Risk Allocation Mainly On The Contractor & & & & & & & & & $\sqrt{ }$ \\
\hline Slow-Decision Making Process & $\sqrt{ }$ & $\sqrt{ }$ & $\sqrt{ }$ & $\sqrt{ }$ & & & & & $\sqrt{ }$ \\
\hline Delay In Government Approvals/Permits Related To Project & $\sqrt{ }$ & $\sqrt{ }$ & $\sqrt{ }$ & & & & & & \\
\hline Delay In Preparation And Approval In Variation Orders & $\sqrt{ }$ & $\sqrt{ }$ & $\sqrt{ }$ & $\sqrt{ }$ & & & & & $\sqrt{ }$ \\
\hline Changed Engineering Conditions From The Contract Document & $\sqrt{ }$ & $\sqrt{ }$ & $\sqrt{ }$ & & & & & & $\sqrt{ }$ \\
\hline Decreased Labor Productivity & & & & $\sqrt{ }$ & $\sqrt{ }$ & $\sqrt{ }$ & & & $\sqrt{ }$ \\
\hline Labor, Materials And Equipment Availability & & & & & $\sqrt{ }$ & $\sqrt{ }$ & & & $\sqrt{ }$ \\
\hline Shortage Of Technical Staff & & & & & $\sqrt{ }$ & $\sqrt{ }$ & & & $\sqrt{ }$ \\
\hline Fluctuating Productivity Levels & & & & & $\sqrt{ }$ & $\sqrt{ }$ & & & $\sqrt{ }$ \\
\hline Client Induced Additional Work Beyond The Original Scope & $\sqrt{ }$ & & & & & & $\sqrt{ }$ & & $\sqrt{ }$ \\
\hline Conflict Between Contractor And Consultant & & & & & & & $\sqrt{ }$ & $\sqrt{ }$ & $\sqrt{ }$ \\
\hline Defective Design & & & & & & & $\sqrt{ }$ & & \\
\hline Lack Of Design Drawings Coordination & & & & & & & $\sqrt{ }$ & & \\
\hline Coordination With Sub-Contractors & & & & & & & & $\sqrt{ }$ & $\sqrt{ }$ \\
\hline Limited Authority Among Supervision Staff & & & & & & & & $\sqrt{ }$ & $\sqrt{ }$ \\
\hline Inadequate Contractor Experience & & & & & & & & $\sqrt{ }$ & $\sqrt{ }$ \\
\hline Contractor Financial Problems & & & & & & & & $\sqrt{ }$ & $\sqrt{ }$ \\
\hline Financial Failure & & & & & & & & $\sqrt{ }$ & $\sqrt{ }$ \\
\hline Owner Financial Problems & & & & & & & & & $\sqrt{ }$ \\
\hline Slow Financial And Payment Procedure & & $\sqrt{ }$ & $\sqrt{ }$ & & & & & & $\sqrt{ }$ \\
\hline Delaying Of Contractor Payments From Owner & & & $\sqrt{ }$ & & & & & & $\sqrt{ }$ \\
\hline Unrealistic Design Development Periods & & & & $\sqrt{ }$ & & & $\sqrt{ }$ & & \\
\hline Lack Of Planning \& Control On The Side Of The Subcontractors & & & & $\sqrt{ }$ & & & & $\sqrt{ }$ & $\sqrt{ }$ \\
\hline Lack Of Planning And Use Of CPM & & & & $\sqrt{ }$ & & & & & $\sqrt{ }$ \\
\hline Poor Scheduling Of Subcontractors & & & & $\sqrt{ }$ & & & & & $\sqrt{ }$ \\
\hline
\end{tabular}




\subsection{List of Recommendations to Delay Occurrence Mitigation}

Based on former discussion, the following list shows recommendations that proposed to mitigate delay occurrence in Kuwait construction industry:

R1 Revise functions and accelerate procedures for change orders in governmental projects

R2 Union agencies for new project approval in governmental projects and define time frame for agencies approval

R3 Accelerate documentation cycle for launching a new project

R4 Enhance planning skills for all project parties

R5 Revise labor supply procedure and accelerate governmental visa procedures especially for big governmental projects

R6 Establish educational and training centers to qualify locals to enter construction labor force

R7 Revise project awarding procedure for consultant by adding qualification criteria to consultant evaluation

R8 Revise project-awarding system for contractor to make sure that the contractor has adequate financial and managerial capability to finish work on time.

R9 Revise and update general contract clauses. This updating should include clauses of planning and schedule by defining time- frame to submit original program, force contractor to submit program revised and updating. In addition to clauses that deal with delay, claims and dispute resolution to be coincide with FIDIC. It recommended also adding a penalty clause for owner delaying payments in general contract.

These recommendations can affect more than one of top-ranked recorded delay causes. Table 4 shows the effect of each one of the proposed recommendations and its effect on the recorded top-ranked delay causes in Kuwait construction projects.

\section{Conclusion}

Many of previous research studies have been focused to identify and evaluate construction delays in construction projects in Kuwait. These delay causes are identified and ranked based on construction personnel judgment. The results of these studies have been used to propose practical recommendations to mitigate effects of delays in Kuwait construction industry. Because of different used phrasing, number of delay causes and group of participants in previous studies, a common procedure is used to unify previous research work results. Previous research work results were ra-grouped and re-ranked. The results are regrouped based on the influencers and re-ranked as top, highly, average, low and no effect on delay causes. Top ranked are gathered and analyzed to propose list of recommendations to mitigate effect of delays in Kuwait construction industry. These recommendations are mainly oriented to governmental projects. Nine recommendations are proposed. These recommendations need governmental motivation to change its procedure of project delivery system for both contractor and consultants. Changing order procedure and function should be revised by governmental agencies.

It is highly recommend revising and updating out of dated general conditions documents. In addition to recommend upgrading all planning skills for all project users.

\section{References}

[1] https://www.csb.gov.kw/Socan_Statistic_EN.aspx?ID=65.

[2] World Bank, Infrastructure development in MENA and the State of Kuwait. Presented at MEED Kuwait Projects Conference. Kuwait, November 2015.

[3] http://www.arabtimesonline.com/news/jaber-hospital-projectrecords-highest-fine-delay-kd-71m-debt-detected-inventory/.

[4] Bramble, B. and Challahan, M., Construction Delay Claims, New York Chichester, John Wiley \& Sons, 1991.

[5] Ahmed, S. M., Azhar, S., kappagagntula, P. and Gollapudi, D. "Delays in Construction: A Brief Study of the Florida Construction Industry" ASCE Proceedings of the $39^{\text {th }}$ Annual Conference. Clemson University, Clemson, South Carolina, USA, April 10-12: 257-266, 2003

[6] Kaming, P., Olomolaiye P., Halt, G. and Frank, H., "Factors Influencing Construction Time and Cost-overruns on High-Rise Projects in Indonesia" Construction Management and Economics, 15, 83-94, 1997.

[7] Bourn, J., Estimating and monitoring the costs of building roads in England. Report by the controller and auditor general, National Audit Office, London, UK, 2003.

[8] Al-Gafly, M., Delay in the Construction of Public Utility Projects in Saudi Arabia. MSC Thesis, KFUPM, Dhahran, Saudi Arabia, 1995.

[9] Hwang, B. G. and Leong, L. P. "Comparison of schedule delay and causal factors between traditional and green construction projects” Technological and Economic Development of Economy, 19(2): 310-330, 2013.

[10] Alaghbari, W., Kadir, M., Ernawati, A. "The significant factors causing delay of building construction projects in Malaysia" Engineering, Construction and Architectural Management, 14(2), 192-206, 2007

[11] Assaf, Sadi A. and Al-Hejji, S. "Causes of delay in large construction projects" International Journal of Project Management, Vol. 24: pp. 349-357, 2006.

[12] Shebob, A.,D., $\mathrm{N}$ and $\mathrm{Xu}, \mathrm{Q}$. "Analyzing construction delay factors: A case study of building construction project in Libya” In: Egbu, C. and Lou, E.C.W. (Eds.) Proceedings of the 27th Annual ARCOM Conference, 5-7 September 2011, Bristol, UK, Association of Researchers in Construction Management,: pp. 1005-1012, 2011.

[13] Fereig, S.M. \& Kartam, N., “Construction Delay in International Projects with Special Reference to the Arabian Gulf Region: Causes, Damage Assessments and Entitlements”, Proceedings of 2nd Project Management Institute, College of Scheduling (PMICOS) Conference, Scottsdale, Arizona, May 2005.

[14] Koushki,P. and Kartam,N. "Impact of construction materials on project time and cost in Kuwait" Engineering, Construction and Architectural Management, Vol. 11 Issue: 2, pp.126-132, 2004.

[15] Soliman, E. “Communication Problems Causing Governmental Projects Delay- Kuwait Case Study" International Journal of Construction Project Management, Volume 9, Number 1, pp 1-18, 2017.

[16] Kartam, N \& Kartam, S. "Risk and Its Management in The Kuwaiti Construction Industry: a Contractor's Prospective” International Journal of Project Management, Vol. 19 (6): 325-335, 2001.

[17] Al-Tabtabai, H. "Causes for Delays in Construction Projects in Kuwait” Engineering Journal of Qatar University, Vol. 15: pp 1937, 2002.

[18] Koushki, P., Al-Rashid, K. and Kartam, N. "Delays and cost increases in the construction of private residential projects in Kuwait” Construction Management and Economic, (23), 285-294, 2005. 
[19] Al Zubaidi, H. and Al Otaibi, S. "An Empirical Approach for Identifying Critical Time-Ovrerun Risk Factors in Kuwait's Construction Projects" Journal of Economic \& Administrative Sciences, 2008.

[20] Soliman, E M. "Delay Causes in Kuwait Construction Projects" AICSGE7, 2010, Strut. Eng. Dept., Fac. of Eng., Alex Univ., Egypt, 2010.

[21] Al Marri, M., Ibrahem, M. and Nassar, G. "Time Delays in Highways Construction Projects in Kuwait” Journal of American Science 8(12):194-197, 2012.

[22] Almutairi, N. "Causes of delays on Construction Projects in Kuwait according to opinion of engineers working in Kuwait" Int. Journal of Engineering Research and Application, Vol. 6, Issue 12, ( Part -3) December 2016, pp.84-96, 2016.

[23] AlSanad, S. "Megaproject and Risk Management L A Case of Kuwait" $5^{\text {th }}$ International of Conference on Sustainable development 6-7 September 2017, Rome, Italy, 2017.

[24] Alshaimi, A. and Koskela, L. "Critical Evaluation if the Previous Delay Studies in Construction" Proceedings of BuHu 8th International Postgraduate Research Conference, June 26-27 2008, Czech Technical University, Prague, Czech Republic, 2008.

[25] Abdul-Rahman, H., and Berawi, M. A. "Power quality system, A new system for quality management in globalization-towards innovation and competitive advantages." Qual. Assur.: Best Practice, Regulation, Law, 9(1): 5-30, 2002

[26] Abdul-Rahman, H., Berawi, M.A., Berawi, A.R., Mohamed, O., M. Othman, M. and I. A. Yahya, I.A. "Delay Mitigation in the Malaysian Construction Industry" Journal of Construction Engineering and Management, Vol. 132 (2): pp 125-133, 2006.

[27] Hamzah, A.; Yahya, I. A.; Berawi, M.A.; Wah, L.W. “Conceptual delay mitigation model using a project learning approach in practice" Construction Management and Economics, 26 (1) :15-27, 2008.

[28] Rani, M. and Hinge. "Delay Mitigation in the construction industry" International Journal of Engineering Research \& Technology (IJERT), Vol 4 (6): pp 172-176, 2015.

[29] Dolage, D. A. R. and Pathmarajah, T. "Mitigation of Delays Attributable to the Contractors in the Construction Industry of Sri Lanka - Consultants. Perspective” ENGINEER - Vol. XLVIII, No. 01, pp. 21-30, 2015.

[30] Srdić, A and Šelih, J. "Delays in Construction Projects: Causes and Mitigation".
[31] Alaryan, A. elbeltagi, E. Elshahat, A. and Dawood, M. "Causes and Effects of Change Orders on Construction Projects in Kuwait" Journal of Engineering Research and Applications, Vol. 4 (7-2): pp.01-08, 2014.

[32] MPW procedure manual - unpublished report, 2004.

[33] Charoennaam, C., Coauinco, S.T. and Hadikusumo, B.H.W. "Web-based application for managing change orders in construction projects" Construction Innovation, Vol. 3 (4): pp. 197-215, 2003.

[34] Halwatura, R.U. and Ranasinghe, N.P. "Causes of Variation Orders in Road Construction Projects in Sri Lanka Construction Engineering" Article ID 381670, 7 pages, 2013.

[35] Msallam, M., Abojaradeh, M., Jrew, B. and Zaki, I. "Controlling Of Variation Orders in Highway Projects in Jordan" Journal of Engineering and Architecture, Vol. 3 (2): pp. 95-104, 2015.

[36] https://www.scpd.gov.kw/followup_report.pdf.

[37] FIDIC: Conditions of Contract for Construction for Building and Engineering Works Designed by the Employer, First Edition, Geneva, 1999.

[38] Central Statistics Bureau (csb). (2014). Kuwait Government Report (www.csb.gov.kw/Socan_Statistic.aspx?ID=29).

[39] Ochieng, E.G. and Price, A.D.F. "Managing cross-cultural communication in multicultural construction project teams: The case of Kenya and UK” International Journal of Project Management, 28: 449-460, 2010.

[40] Loosemore, M. and Lee, P. "Communication Problems with Ethnic Minorities in The construction Industry" International Journal of Project Management, 20: 517-524, 2002.

[41] Konchar, M, and Sanvido, V. "Comparison of U.S. Project Delivery Systems" Journal of Construction Engineering and Management, 124(6): 435-444, 1998.

[42] Kashiwagi, D. (2014). Information measurement theory with the Kashiwagi story. Retrieved from www.KSM-Inc.com.

[43] Alzara, M., Kashiwagi, J., Kashiwagi, D. and Al-Tassan, A. "Using PIPS to minimize causes of delay in Saudi Arabian construction projects: university case study" Procedia Engineering, 145: 932-939, 2016.

[44] Kerzner, H., Project Management A System Approach to Planning Scheduling and Controlling, John Wiley \& Sons, Inc. Hoboken, New Jersey, 2013. 